\title{
Efecto de tratamientos pre germinativos e inoculación microbiana en cacahuate (Arachis hypogaea L.)*
}

\author{
Effect of pre-germinate treatments and microbial \\ inoculation in peanut (Arachis hypogaea L.)
}

\begin{abstract}
Esaú Ruiz-Sánchez ${ }^{1}$, Martín Canul-Díaz ${ }^{1}$, Jesse Pacheco-Aguirre ${ }^{1}$,Alfonzo Pérez-Gutiérrez ${ }^{1}$,Arturo Reyes-Ramírez ${ }^{1}$ y Horacio S. Ballina-Gómez ${ }^{1 \S}$

${ }^{1}$ Instituto Tecnológico de Conkal-Departamento de Fitopatología. Antigua Carretera Mérida-Motul, km 16.3, Conkal, Yucatán, México. C. P. 97345. Tel: 01 52 999 912 4135.(esau_ruiz@hotmail.com; mecd388@hotmail.com;jessep2010@gmail.com; riegoeficiente@hotmail.com; arte_rey@hotmail.com).^Autor para correspondencia: horacio.ballina@itconkal.edu.mx.
\end{abstract}

\section{Resumen}

El cultivo de cacahuate (Arachis hypogaea L.), ampliamente utilizadoporlosagricultores porsurentabilidadymejoramiento de las propiedades físicas y químicas edáficas, presenta una prolongada latencia de semillas, que va hasta seis meses. En otras especies vegetales la latencia de semillas se ha tratado con inductores de germinación como el ácido giberélico $\left(\mathrm{AG}_{3}\right)$, el ácido indolacético y naproxeno (NPX). Otro problema técnico en el cultivo de cacahuate es el crecimiento lento de las primeras etapas de las plantas. Lo anterior podría incrementar con el uso de cepas bacterianas promotoras de crecimiento. El objetivo del presente trabajo fue evaluar el efecto del $\mathrm{AG}_{3}$ yNPX como inductores de germinación, y cepas de Bacillus spp. como promotoras de crecimiento vegetal. En la germinación se usaron dos concentraciones y dos tiempos de inmersión en $\mathrm{AG}_{3}$ y NPX, mientras que para mejorar crecimiento se usaron tres cepas de Bacillus spp. (CBTC1, CBCC57 y CBRF12) como inoculantes. La germinación incrementó con el tratamiento de $10 \mathrm{mg} \mathrm{mL}^{-1} \mathrm{de} \mathrm{AG}_{3}$; entanto, la tasa relativa de crecimiento en altura de las plantas aumentó significativamente a los 15 días después de la siembra, cuando se inocularon con la cepa CBRF12 de Bacillus spp.Asimismo, se encontró un mayor crecimiento significativo de la biomasa seca de la raíz a los 30 días luego de la siembra, con la cepa CBTC1. En conclusión, el porcentaje de germinación de $A$.

\section{Abstract}

Peanut crop (Arachis hypogaea L.) is widely used by farmers for their profitability and improvement of the physical and chemical soil traits has a prolonged seed dormancy, which runs up to six months. In other plant species, seed dormancy has been treated with inducers of germination, such as gibberellic acid $\left(\mathrm{AG}_{3}\right)$, indoleacetic acid and Naproxen (NPX).Another technical issue in the peanut crop is the slow growth of the early stages of the plants. This would increase with the use of bacterial strains to growth promoters. The aim of this study was to evaluate the effect of $\mathrm{AG}_{3}$ and NPX as inducers of germination, and strains of Bacillus spp. as promoting plant growth. Germination and two times two concentrations immersion in $\mathrm{AG}_{3}$ and NPX were used, while three strains of Bacillus spp were used as inoculants to enhance growth (CBTC1, CBCC57 and CBRF12). Germination increased with the treatment of $10 \mathrm{mg} \mathrm{mL}^{-1}$ of $\mathrm{AG}_{3}$; meanwhile, the relative growth rate in height of the plants was significantly increased at 15 days after sowing, when inoculated with the strain of Bacillus spp CBRF12. We also found a significantly larger increase in root dry biomass at 30 days after planting, with the CBTC 1 strain. In conclusion, the percentage of germination of $A$. hypogaeae increased with the addition of $\mathrm{AG}_{3}$. Also, the growth of the plant increased, albeit slightly, and other significantly only

\footnotetext{
* Recibido: enero de 2015

Aceptado: abril de 2015
} 
hypogaeae incrementó con la adición de $\mathrm{AG}_{3}$. Por su parte, el crecimiento de la planta aumentó, aunque ligeramente, sí de forma significativa y sólo en algunas variables, por la inoculación de las cepas de Bacillus spp. Los resultados del presente estudio muestran la capacidad del AG para romper la latencia de semillas de cacahuate; así como las ventajas de usar bacterias promotoras de crecimiento, en el incremento de la altura y la biomasa de raíces de esta especie vegetal. Esto podría ser de gran ayuda en la producción de cacahuate, al disminuir el tiempo de latencia y acelerar el crecimiento.

Palabras clave: Bacillus spp., ácido giberélico, crecimiento vegetal, latencia, naproxeno.

\section{Introducción}

El cultivo de cacahuate (Arachis hypogaea L.) se utiliza ampliamente por los agricultores debido a su rentabilidad, que puede tener una relación beneficio/costo hasta de 1.7 dependiendo de la productividad de la variedad(Duque, 2013), y potencial para mejorar las propiedades físicas y químicas del suelo (Ossom y Rhykerd, 2008). A nivel internacional el cacahuate es el tercerproducto oleaginoso producido, después de la soya y el algodón (Financiera Rural, 2011). Los frutos de cacahuate, junto con soya, algodón, canola y girasol, tienen alto contenido de aceite (aproximadamente 50\%) y proteínas (22-30\%), también contiene hidratos de carbono, minerales y vitaminas (Ingale y Shrivastava, 2011). Debido a estas características, los frutos de $A$. hypogaea integra la dieta diaria en algunas regiones de África y Asia, donde la situación alimentaria es precaria (Kambiranda et al., 2011). En México, a pesar de las bondades del cultivo, la superficie sembrada disminuyó en casi $40 \%$ en la última década, en la actualidad la superficie cultivada con esta oleaginosa es de aproximadamente de 60000 hectáreas, con una producción de 2.8 y 1.3 toneladas por hectárea, en riego y temporal, respectivamente (Financiera Rural, 2011).

Lasemilla de A. hypogaea recién cosechada, fisiológicamente madura y viable, no germina cuando se coloca en condiciones óptimas de luz, temperatura, oxígeno y contenido de humedad (Qin et al., 2012). Este fenómeno se presenta en muchas especies oleaginosas, en las cuales la intensidad y duración del reposo depende del cultivar así como de las condiciones de cultivo y de almacenamiento. Se ha determinado que las semillas de $A$. hypogaea no germinan inmediatamente después de ser cosechadas, sino hasta 4-6 meses posteriores (Navarro et al., 2012). in some variables, by inoculating the strains of Bacillus spp. The results of this study show $\mathrm{AG}_{3}$ capacity to break seed dormancy on peanuts; as well as the advantages of using growth promoting bacteria in the increase of height and root biomass of this plant species. This could be helpful in peanut production by reducing latency and accelerate growth.

Keywords: Bacillus spp, gibberellic acid, latency, naproxen, plant growth.

\section{Introduction}

The peanut crop (Arachis hypogaea L.) is widely used by farmers because of its profitability, which may have a benefit/cost ratio to 1.7 depending on the productivity of the variety (Duque, 2013), and potential to improve physical and chemical soil traits (Ossom and Rhykerd, 2008). Worldwide, the peanut is the third oil product produced, after soybean and cotton (Financiera Rural, 2011). Peanut fruit, along with soybeans, cotton, canola and sunflower have high oil content (about 50\%) and protein (22-30\%), also contains carbohydrates, minerals and vitamins (Ingale and Shrivastava, 2011). Because of these characteristics, the fruits of $A$. hypogaea is part of the daily diet in parts of Africa and Asia, where the food situation is precarious (Kambiranda et al., 2011). In Mexico, despite the benefits of crop acreage decreased by almost $40 \%$ in the last decade, currently cultivated with this oilseed area is approximately 60000 hectares, with a production of 2.8 and 1.3 tons per hectare, irrigation and temporal, respectively (Financiera Rural, 2011).

The seed of A. hypogaea freshly harvested physiologically mature and viable, do not germinate when placed in optimal conditions of light, temperature, oxygen and moisture content (Qin et al., 2012). This phenomenon occurs in many oilseed species, in which the intensity and duration of sleep depends on cultivar and growing conditions and storage. It has been determined that, the seeds of $A$. hypogaea do not germinate immediately after being harvested, but up to 4-6 months (Navarro et al., 2012).

In order to shorten the rest of $A$. hypogaea, different treatments have been tried, for example, Gómez et al. (2001) found that the use of high, temperatures close to $40{ }^{\circ} \mathrm{C}$ significantly stimulates germination. Moreover, 
Con el fin de acortar el periodo de reposo de A. hypogaea, se han probado diferentes tratamientos, por ejemplo, Gómez et al. (2001) encontró que el uso de temperaturas altas, cercanas a $40^{\circ} \mathrm{C}$ estimula significativamente la germinación. Por otra parte, dentro de los tratamientos químicos, el uso de etileno ha demostrado ser eficiente para promover la germinación; este compuesto, a concentraciones de $8 \mathrm{~g} \mathrm{~L}^{-1}$, por periodos de 48 horas, produce resultados similares a los obtenidos por tratamientos con calor (Lin et al., 2009; Nawangsih et al., 2012).

Otro regulador que podría actuar de manera indirecta sobre la germinación en semillas es el naproxeno (NPX), ya que es considerado un inhibidor de la biosíntesis del ácido abscísico (ABA), la cual es una hormona vegetal, involucrada en diferentes procesos fisiológicos del crecimiento y desarrollo de la planta, como la dormancia en las semillas (Cassán et al., 2008). Se ha reportado que el tratamiento de semillas con NPX disminuye significativamente los niveles de $\mathrm{ABA}$ endógeno y el gen de transcripción AhNCED1 en la germinación de la semilla, proporcionando un aumento en la actividad de la $\alpha$-amylasa, cuyo efecto se traduce en incremento de la tasa de germinación e índice de viabilidad en la germinación (Hu et al., 2010).

Por otra parte, el crecimiento inicial de la planta constituye una fase importante en el desarrollo del cultivo, ya que mediante el rápido establecimiento de elevado número de tallos primarios, generación y expansión del sistema foliar e incremento en expansión radicular, las plantas incrementan su capacidad competitiva y de absorción de nutrientes del suelo (Mohammadi, 2013). En este sentido, una alternativa para promover el crecimiento inicial es la aplicación de microorganismos promotores de crecimiento vegetal, los cuales pueden actuar por diferentes vías, como fijación de nitrógeno atmosférico, producción de fitohormonas, y solubilización de elementos minerales (Gutiérrez et al., 2001). Estos microrganismos pueden ser explotados como una estrategia sustentable para incrementar la productividad de A. hypogaea (Muñoz et al., 2011).

El objetivo de este trabajo fue evaluar el efecto del ácido giberélico y naproxeno como inductores de germinación, y el efecto posterior de Bacillus spp. como promotor de crecimiento en plantas de Arachis hypogaea L. within the chemical treatments, the use of ethylene has proved efficient to promote germination; this compound at concentrations of $8 \mathrm{~g} \mathrm{~L}^{-1}$, for periods of 48 hours produces similar to those obtained by heat treatments results (Lin et al., 2009; Nawangsih et al., 2012).

Another regulator which could act indirectly on germination in seeds is Naproxen (NPX) because it is considered an inhibitor of the biosynthesis of abscisic acid (ABA), which is a plant hormone involved in different physiological processes of growth and plant development such as seed dormancy (Cassán et al., 2008). It has been reported that, the treatment of seeds with NPX significantly lowers the levels of endogenous $\mathrm{ABA}$ and gene transcription AhNCED1 in seed germination, providing an increase in the activity of $\alpha$-amylase, which effect results in increased germination rate and index of germination viability $(\mathrm{Hu}$ et al., 2010).

Moreover, the initial growth of the plant is an important phase in the development of the crop, and that by the rapid establishment of large number of main stems, leaf generation system expansion and increased root growth, increase plant capacity competitive and absorption of nutrients from the soil (Mohammadi, 2013). In this regard, an alternative to promote the initial growth is the application of plant growth promoting microorganisms, which may act in different ways, such as nitrogen fixation, production of phytohormones, and solubilization of minerals (Gutiérrez et al., 2001). These microorganisms can be exploited as a sustainable strategy to increase the productivity of $A$. hypogaea (Muñoz et al., 2011).

The aim of this study was to evaluate the effect of gibberellic acid and naproxen as inducing germination and subsequent effect of Bacillus spp. as plant growth promoter of Arachis hypogaea $\mathrm{L}$.

\section{Materials and methods}

\section{Location of the experiment}

Seed treatment and preparation of bacterial inoculum were performed in the Laboratory of Microbiology Conkal Institute of Technology, Yucatan, Mexico. The evaluation 


\section{Materiales y métodos}

\section{Ubicación del experimento}

El tratamiento de semillas y la preparación de inóculos bacterianos se llevaron a cabo en el Laboratorio de Microbiología del Instituto Tecnológico de Conkal, Yucatán, México. El experimento de evaluación de inoculantes microbianos y germinación se llevó a cabo en la ciudad de Hunucmá, Yucatán, México, ubicada a $21^{\circ} 10^{\prime}$ 0" latitud norte y $90^{\circ} 2^{\prime} 0^{\prime \prime}$ longitud oeste. Hunucma presenta un clima calido semihumedo con lluvias en verano, una temperatura media anual de $26^{\circ} \mathrm{C}$ y una precipitación media anual que va de 400 a $1200 \mathrm{~mm}$ (INEGI, 2010).

\section{Obtención de las semillas}

Las semillas de A. hypogaea de origen criollo, se obtuvieron en el municipio El Parral, Chiapas, México. Presenta las siguientes: arbusto que produce dos almendras por vaina y el tiempo de emergencia a cosecha es de 110-120 días. Las semillas usadas en los experimentos pre germinativos no tuvieronmás de 30 días después de la cosechay las usadas para la evaluación de inoculantes microbianos no más de 12 meses.

\section{Aplicación de tratamientos pre germinativos en cacahuate}

Para la evaluación del efecto del ácido giberélico $\left(\mathrm{AG}_{3}\right)$ y naproxeno (NPX) en la inducción de germinación de A. hypogaea, se seleccionaron semillas en buen estado y tamaño homogéneo. Estas se separaron en lotes de 10 para cada repetición de los tratamientos. Las semillas se introdujeron en soluciones que contenían cada promotor de germinación a dos concentraciones y el testigo, y dos tiempos de inmersión (Cuadro 1). El experimento se estableció bajo un diseño completamente al azar. En cada tratamiento se emplearon tres réplicas.

\section{Evaluación de la germinación}

Las semillas tratadas con $\mathrm{AG}_{3}$ y NPX se dejaron secar a temperatura ambiente durante siete días. Una vez secas se sembraron con el hipocotilo hacia abajo en sustrato Cosmopeat ${ }^{\circledR}$ empleando charolas de polietileno de $10 \times 20$ $\mathrm{cm}$. Las charolas se mantuvieron al aire libre a temperatura ambiente y con riego diario, para mantener el sustrato a capacidad de campo. Las variables respuesta para cada experiment of microbial inoculants and germination took place in the city of Hunucmá, Yucatan, Mexico, located at $2^{\circ} 10^{\prime} 0^{\prime \prime}$ North latitude and $90^{\circ} 2^{\prime} 0^{\prime \prime}$ West longitude. Hunucmá has a semi-humid warm climate with summer rains, an average annual temperature of $26{ }^{\circ} \mathrm{C}$ and an annual rainfall ranging from 400 to $1200 \mathrm{~mm}$ (INEGI, 2010).

\section{Obtaining seeds}

The seeds of $A$. hypogaea of Native origin is obtained in the municipality of El Parral, Chiapas, Mexico. Presents the following: almond bush produces two per pod and time of emergence to harvest is 110-120 days. The seeds used in the pre germination experiments were not more than 30 days after harvest and used for evaluation of microbial inoculants no more than 12 months.

\section{Application of pre-treatments in peanut germ}

In order to evaluate the effect of gibberellic acid $\left(\mathrm{AG}_{3}\right)$ and naproxen (NPX) in inducing germination of $A$. hypogaea seeds were selected in good shape and uniform size. These were separated into groups of 10 for each repeat treatments. The seeds were placed in solutions containing each promoter germination at two concentrations and the witness, and two-time immersion (Table 1). The experiment was set under a completely randomized design. Three replicates per treatment were used.

Cuadro 1. Condiciones experimentales para la evaluación de tratamientos pre germinativos en $A$. hypogaea.

Table 1. Experimental conditions for evaluating treatments in pre-germ $A$. hypogaea.

\begin{tabular}{cccc}
\hline *Tratamientos & $\begin{array}{c}\text { Tipo de } \\
\text { promotor de } \\
\text { germinación }\end{array}$ & $\begin{array}{c}\text { Cantidad del } \\
\text { promotor } \\
\text { en agua } \\
\left(\mathrm{mg} \cdot 100 \mathrm{~mL}^{-1}\right)\end{array}$ & $\begin{array}{c}\text { Tiempo de } \\
\text { inmersión en } \\
\text { la solución } \\
\text { promotora (h) }\end{array}$ \\
\hline $\mathrm{T} 1$ & $\mathrm{AG}_{3}$ & 10 & 2 \\
$\mathrm{~T} 2$ & $\mathrm{AG}_{3}$ & 10 & 4 \\
$\mathrm{~T} 3$ & $\mathrm{AG}_{3}$ & 20 & 2 \\
$\mathrm{~T} 4$ & $\mathrm{AG}_{3}$ & 20 & 4 \\
$\mathrm{~T} 5$ & $\mathrm{NPX}$ & 37.5 & 2 \\
$\mathrm{~T} 6$ & $\mathrm{NPX}$ & 37.5 & 4 \\
$\mathrm{~T} 7$ & $\mathrm{NPX}$ & 81.25 & 2 \\
T8 & $\mathrm{NPX}$ & 81.25 & 4 \\
Testigo & Agua & 0 & 4 \\
& destilada & & \\
\hline
\end{tabular}

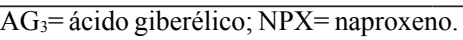


tratamiento se calcularon como lo indica Ranal et al.(2009): porcentaje de germinación, tiempo medio de germinación, coeficiente de variación del tiempo de germinación, velocidad media de germinación e incertidumbre de germinación. Los datos para cada variable fueron tomados diariamente a la misma hora durante 15 días. Se consideró como semilla germinada al momento de la aparición de la radícula.

\section{Efecto de Bacillus spp. en plántulas de A. hypogaea}

Para la evaluación Bacillus spp. como promotor de crecimiento, se utilizaron tres cepas bacterianas (CBTC1, CBCC57 y CBRF12) del cepario conservado en el laboratorio de Microbiología del Instituto Tecnológico de Conkal, Yucatán, México. Las cepas fueron aisladas inicialmente de la península de Yucatán, de muestras de suelo de la rizosfera de diversos cultivos y malezas (Sosa-Pech et al., 2012). Estas fueron reproducidas en agar nutritivo a temperatura de incubación de $30^{\circ} \mathrm{C}$. Las esporas se obtuvieron por raspado de las colonias y suspensión sucesiva en un matraz Erlenmeyer con $100 \mathrm{~mL}$ agua estéril hasta tener una concentración de $1 \times 10^{8} \mathrm{CFU} \mathrm{mL}^{-1}$. La inoculación de las cepas bacterianas se realizó en plantas de $A$. hypogaea de tres días de emergencia, se aplicaron $3 \mathrm{ml}$ de suspensión bacteriana a las plántulas establecidas en charolas de polietileno de 10 x $20 \mathrm{~cm}$ con sustrato Cosmopeat ${ }^{\circledR}$. El experimento se estableció bajo un diseño completamente al azar. Se utilizaron 10 plántulas por repetición. Se tuvieron tres repeticiones para cada tratamiento (cepa bacteriana). El testigo consistió de plantas sin inocular.

Tres días después de la primera inoculación, las plántulas fueron trasplantadas en vasos de poliestireno de $600 \mathrm{~mL}$ con una mezcla de suelo, gravilla y Cosmopeat ${ }^{\mathbb{}}$, en proporción volumétrica de $50 \%, 20 \%$ y $30 \%$, respectivamente; y a los 15 días posteriores a la primera inoculación, se llevó a cabo una segunda inoculación con $3 \mathrm{ml}$ de suspensión bacteriana, la cual fue obtenida como se describió anteriormente. Todas las plantas se mantuvieron a riego constante hasta su evaluación final.

\section{Evaluación de promoción del crecimiento de $A$. hypogaea}

Alos 15 y 30 días después del trasplante, se evaluó la altura de la planta, diámetro del tallo, número de hojas, biomasa fresca y seca (tallo, raíz y hojas) y la tasa relativa de crecimiento. En el caso de la biomasa seca, las muestras se secaron a peso constante en una estufa de convección a $70{ }^{\circ} \mathrm{C}$ durante 48 horas. La RGR se calculó de acuerdo al método de Causton y Venus (1981) usando los datos de biomasa seca $\left(\mathrm{RGR}_{\text {Bio, }}\right.$,

\section{Evaluation of germination}

Seeds treated with $\mathrm{AG}_{3}$ and NPX allowed to dry at room temperature for seven days. Once dry seeded with hypocotyl down Cosmopeat ${ }^{\circledR}$ substrate using polyethylene trays $10 \mathrm{x}$ $20 \mathrm{~cm}$. Outdoor trays at room temperature and maintained daily watering to keep the soil at field capacity. The response variables were calculated for each treatment as indicated by Ranal et al. (2009): germination percentage, mean germination time, coefficient of variation of germination time, average speed of germination and germination uncertainty. The data for each variable were taken daily at the same time for 15 days. It was considered germinated seed at the radicle.

\section{Effect of Bacillus spp. on seedlings of A. hypogaea}

For the evaluation Bacillus spp. as growth promoter, three bacterial strains (CBTC1, CBCC57 and CBRF12) the strain collection maintained in the laboratory of Microbiology Conkal Institute of Technology, Yucatan, Mexico were used. The strains were initially isolated from the Yucatan Peninsula, soil samples from the rhizosphere of various crops and weeds (Sosa-Pech et al., 2012). These were replicated on a nutrient agar incubation temperature of $30^{\circ} \mathrm{C}$. The spores were scraped from the colonies and subsequent suspension in a $100 \mathrm{ml}$ Erlenmeyer flask with sterile water to a concentration of $1 \times 10^{8}$ $\mathrm{CFU} \mathrm{mL} \mathrm{m}^{-1}$. Inoculation of the bacterial strains was performed in plants of $A$. hypogaea at three days of emergence, $3 \mathrm{ml}$ of bacterial suspension were applied to the seedlings established in polyethylene trays $10 \times 20 \mathrm{~cm}$ with Cosmopeat ${ }^{\mathbb{}}$ substrate. The experiment was set under a completely randomized design. 10 seedlings per replication were used. Three replicates for each treatment (bacterial strain) were taken. The control consisted of uninoculated plants.

Three days after the first inoculation, the seedlings were transplanted into polystyrene cups with $600 \mathrm{~mL}$ of a mixture of soil, gravel and Cosmopeat ${ }^{\circledR}$, in volumetric ratio of $50 \%, 20 \%$ and $30 \%$ respectively; and 15 days after the first inoculation was conducted a second inoculation with $3 \mathrm{ml}$ of bacterial suspension, which was obtained as described above. All plants were maintained at constant watering to its final evaluation.

\section{Evaluation of promoting the growth of $A$. hypogaea}

At 15 and 30 days after transplanting, plant height, stem diameter, number of leaves, fresh and dried (stem, root and leaves) biomass and relative growth rate were evaluated. In 
$\mathrm{g} \mathrm{g}^{-1}$ día $\left.^{-1}\right)$, altura del tallo $\left(\mathrm{RGR}_{\mathrm{Alt}}, \mathrm{cm} \mathrm{cm}^{-1}\right.$ día $\left.^{-1}\right)$ y diámetro del tallo $\left(\mathrm{RGR}_{\text {Dia }}, \mathrm{mm} \mathrm{mm}^{-1}\right.$ día $\left.^{-1}\right)$ mediante la siguiente ecuación:

$\mathrm{RGR}=\frac{\operatorname{In}\left(\mathrm{B}_{2}\right)-\operatorname{In}\left(\mathrm{B}_{1}\right)}{\left(\mathrm{t}_{1}-\mathrm{t}_{2}\right)}$

Donde $=\mathrm{B}_{1}=$ biomasa inicial $; \mathrm{B}_{2}=$ biomasa final; $\mathrm{t}_{1}=$ tiempo al inicio; $\mathrm{t}_{2}=$ tiempo en días transcurridos del experimento.

\section{Análisis de datos}

Los datos fueron analizados mediante análisis de varianza de efectos principales (ANOVA) para cada variable de respuesta, en la germinación los factores fueron la concentración de los inductores y el tiempo de respuesta (horas); y en el crecimiento los factores fueron la cepa bacteriana y el tiempo de respuesta (días). Todos los análisis se realizaron en Statistica v.8 (2007). Los datos fueron expresados como medias y desviaciones estándar. Previo a los análisis, únicamente los datos de porcentaje se transformaron con el arcoseno de la raíz cuadrada para lograr los supuestos de normalidad e igualdad de varianza.

\section{Resultados y discussion}

\section{Efecto de los tratamientos pre germinativos}

Los tratamientos pre germinativos afectaron de forma significativa $(p<0.05)$ la germinación de las semillas de cacahuate. Aunque sólo el tratamiento T2 $\left(10 \mathrm{mg} 100 \mathrm{~mL}^{-1}\right.$ de $\mathrm{AG}_{3}$ por $4 \mathrm{~h}$ ) (Cuadro 1) incrementó la germinación hasta $53 \%$. El resto de los parámetros del proceso germinativo no presentaron diferencias estadísticamente significativas (Cuadro 2; Figura 1). the case of dry biomass, the samples were dried to constant weight in a convection oven at $70{ }^{\circ} \mathrm{C}$ for 48 hours. The RGR was calculated according to the method of Causton and Venus (1981) using data of dry biomass (RGR Bio, $\mathrm{g} \mathrm{g}^{-1}$ day $\left.^{-1}\right)$, stem height $\left(\mathrm{RGR}_{\mathrm{Alt}}, \mathrm{cm} \mathrm{cm}^{-1} \mathrm{day}^{-1}\right)$ and diameter stem $\left(\mathrm{RGR}_{\text {Dia }}, \mathrm{mm} \mathrm{mm}^{-1} \mathrm{day}^{-1}\right)$ by the following equation:

$\mathrm{RGR}=\frac{\operatorname{In}\left(\mathrm{B}_{2}\right)-\operatorname{In}\left(\mathrm{B}_{1}\right)}{\left(\mathrm{t}_{1}-\mathrm{t}_{2}\right)}$

Where $=\mathrm{B}_{1}=$ initial biomass; $\mathrm{B}_{2}=$ final biomass; $\mathrm{t}_{1}=$ time at the beginning; $t_{2}=$ time elapsed days of the experiment.

\section{Data analysis}

Data were analysed using analysis of variance main effects (ANOVA) for each response variable, in germination were the concentration factor of the inductors and the response time (hours); and growth factors were the bacterial strain and the response time (days). All analyses were performed in Statistica v.8 (2007). Data were expressed as means and standard deviations. Prior to the analysis, only the percentage data were transformed to arcsine square root to achieve the assumptions of normality and equal variance.

\section{Results and discussion}

\section{Effect of pre-germinative treatments}

The pre-germ treatments affected significantly $(p<0.05)$ germination of seeds of peanut. Although, only T2 (10 mg $100 \mathrm{~mL}^{-1}$ of $\mathrm{AG}_{3}$ per $4 \mathrm{~h}$ ) (Table 1) treatment increased germination to $53 \%$. The rest of the germination process parameters did not show statistically significant differences (Table 2, Figure 1).

Cuadro 2. Efecto de los tratamientos en la germinación de $A$. hypogaea.

Table 2. Effect of treatments on the germination of $A$. hypogaea.

\begin{tabular}{llllll}
\hline Tratamientos & Germinación $(\%)$ & MT & CVT & MR & I \\
\hline T1 & $33.33 \pm 3.33 \mathrm{ab}$ & $8.92 \pm 0.43 \mathrm{a}$ & $54.74 \pm 2.51 \mathrm{a}$ & $0.11 \pm 0.01 \mathrm{a}$ & $1.56 \pm 0.03 \mathrm{a}$ \\
T2 & $53.33 \pm 3.33 \mathrm{a}$ & $7.11 \pm 0.63 \mathrm{a}$ & $38.40 \pm 3.77 \mathrm{a}$ & $0.14 \pm 0.01 \mathrm{a}$ & $1.70 \pm 0.4 \mathrm{a}$ \\
T3 & $30.00 \pm 0.00 \mathrm{ab}$ & $7.11 \pm 0.29 \mathrm{a}$ & $19.86 \pm 9.16 \mathrm{a}$ & $0.14 \pm 0.01 \mathrm{a}$ & $1.36 \pm 0.22 \mathrm{a}$ \\
T4 & $36.67 \pm 8.82 \mathrm{ab}$ & $7.33 \pm 0.88 \mathrm{a}$ & $55.23 \pm 14.97 \mathrm{a}$ & $0.14 \pm 0.02 \mathrm{a}$ & $1.61 \pm 0.38 \mathrm{a}$ \\
T5 & $26.67 \pm 6.67 \mathrm{~b}$ & $8.33 \pm 2.85 \mathrm{a}$ & $27.08 \pm 11.94 \mathrm{a}$ & $0.15 \pm 0.04 \mathrm{a}$ & $1.17 \pm 0.17 \mathrm{a}$ \\
T6 & $23.33 \pm 8.82 \mathrm{~b}$ & $9.50 \pm 1.89 \mathrm{a}$ & $52.61 \pm 25.96 \mathrm{a}$ & $0.11 \pm 0.02 \mathrm{a}$ & $0.83 \pm 0.44 \mathrm{a}$ \\
T7 & $16.67 \pm 3.33 \mathrm{~b}$ & $4.83 \pm 0.17 \mathrm{a}$ & $22.00 \pm 6.29 \mathrm{a}$ & $0.21 \pm 0.01 \mathrm{a}$ & $0.67 \pm 0.33 \mathrm{a}$ \\
T8 & $23.33 \pm 3.33 \mathrm{~b}$ & $6.72 \pm 1.67 \mathrm{a}$ & $41.05 \pm 16.02 \mathrm{a}$ & $0.17 \pm 0.03 \mathrm{a}$ & $1.19 \pm 0.20 \mathrm{a}$ \\
Testigo & $20.00 \pm 0.00 \mathrm{~b}$ & $8.00 \pm 1.04 \mathrm{a}$ & $17.77 \pm 5.34 \mathrm{a}$ & $0.13 \pm 0.01 \mathrm{a}$ & $1.00 \pm 0.00 \mathrm{a}$ \\
\hline
\end{tabular}

Letras diferentes dentro de una columna indican diferencia estadística (Tukey< $<0.05$ ). MT= tiempo medio de germinación; CVT= coeficiente de variación del tiempo; $\mathrm{MR}=$ velocidad media de germinación; $\mathrm{I}=$ incertidumbre . 
La respuesta a la germinación en todos los tratamientos evaluados en el presente estudio se consideró baja con respecto a lo que han reportado otros autores para el caso de semillas de $A$. hypogaea, donde han documentado hasta 64\% de germinación (Saravanakumar y Samiyappan, 2007; Shweta et al., 2008). Es importante tomar en cuenta que existe amplia variación en la latencia de los diferentes genotipos de esta especie, de tal manera que el efecto de inductores de germinación puede ser diferencial en los diferentes materiales genéticos o incluso lotes del mismo material (Enríquez y Quero, 2001). En el presente trabajo, se obtuvieron efectos significativos $(p<0.05)$ en la germinación de $A$. hypogaea para el tratamiento T2 (10 $\mathrm{mg} 100 \mathrm{~mL}^{-1}$ de $\mathrm{AG}_{3}$ por $4 \mathrm{~h}$ ) con un incremento de $33.33 \%$, respecto al testigo (Figura 1). En general, el ácido giberélico ha sido usado con éxito en la promoción de la germinación de semillas. En este sentido, Atrip y O'Reilly (2007) observaron un incremento de $15 \%$ en la germinación de la semilla de Betula pubescens sobre el control, usando ácido giberélico $\left(20 \mathrm{mg} 100 \mathrm{~mL}^{-1}\right)$.

Por su parte, Thammina et al. (2012) reportaron un incremento de $26 \%$ en la germinación de semillas de Euonymus alatus sobre el control, usando una concentración baja de ácido giberélico $\left(0.05 \mathrm{mg} 100 \mathrm{~mL}^{-1}\right)$. En nuestro estudio, se confirma que el ácido giberélico ayuda a eliminar la latencia de las semillas de $A$. hypogaea y proporciona una mayor germinación de ellas. Aunque en el presente estudio se encontró que el mayor porcentaje de germinación fue a un tiempo de imbibición de 4 horas, Herrera-Corredor et al. (2011) mencionan que semillas de Allium cepa con tiempos de imbibición con la hormonaBAP(benziladenina)mayores a 5 min disminuyen sus porcentajes de germinación. En este sentido, habría la necesidad de mayores estudios con $\mathrm{AG}_{3}$, ya que son casi nulos en la actualidad.

Por otra parte, no se observaron efectos significativos del naproxeno sobre la germinación de A. hypogaea. En trabajos previos, el naproxeno se ha considerado un inhibidor de la biosíntesis del ácido abscísico (ABA), que permite incrementar la germinación de semillas (Wan y Li, 2006). Inlcusive, Hu et al. (2010) reportan que la aplicación de naproxeno por $12 \mathrm{~h}$ aproximadamente incrementa la germinación de $A$. hypogaea hasta $96 \%$, seis días después de la aplicación. Aquí, la aplicación de naproxeno fue solamente por 2 ó $4 \mathrm{~h}$, lo cual pudo haber afectado el resultado, pues el tiempo de exposición y la concentración de naproxeno son factores determinantes en la germinación de A. hypogaea (Matusova et al., 2005).

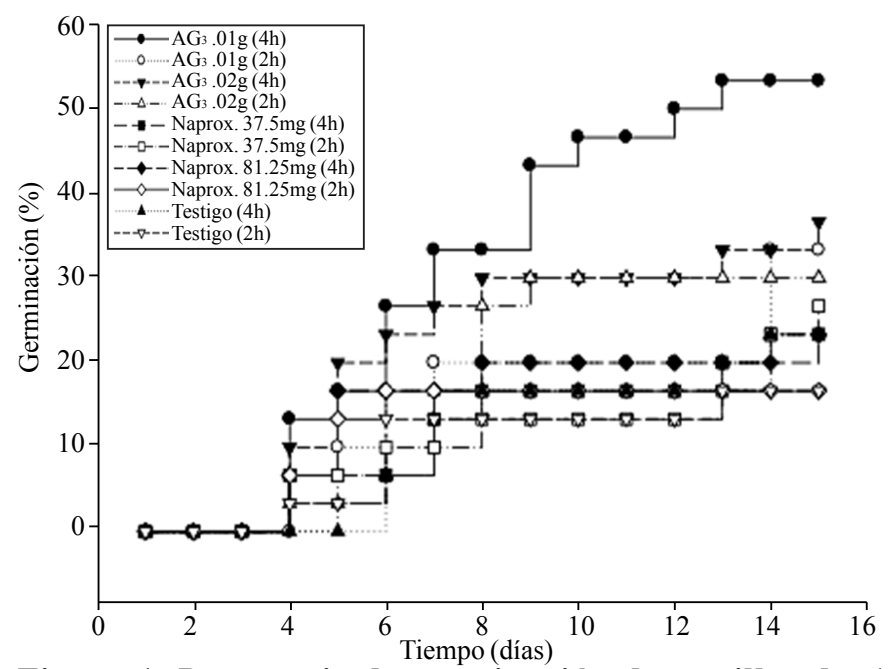

Figura 1. Porcentaje de germinación de semillas de $\boldsymbol{A}$. hypogaea. $\mathrm{AG}_{3}=$ ácido giberélico.

Figure 1. Percentage of germination of $A$. hypogaea. $\mathrm{AG}_{3}=$ gibberellic acid.

The answer to the germination in all treatments evaluated in this study was considered low compared to what other authors have reported the case of seeds of A. hypogaea, where they have documented up to $64 \%$ germination (Saravanakumar and Samiyappan, 2007; Shweta etal., 2008). It is important to note that there is wide variation in the latency of the different genotypes of this species, so that the effect of inducing germination can be spread in different genetic materials or even lots of the same material (Enríquez and Quero, 2001). In this paper, significant effects $(p<0.05)$ were obtained in the germination of $A$. hypogaea for T2 $(10 \mathrm{mg} 100 \mathrm{~mL}-1$ of $\mathrm{AG}_{3}$ to $4 \mathrm{~h}$ ) treatment with an increase of $33.33 \%$ compared to the control (Figure 1). Generally, gibberellic acid has been successfully used to promote seed germination. In this sense, ATRIP and O'Reilly (2007) observed a 15\% increase in seed germination of Betula pubescens on control, using gibberellic acid $\left(20 \mathrm{mg} 100 \mathrm{~mL}^{-1}\right)$.

Thammina et al. (2012) reported a 26\% increase in seed germination of Euonymus alatus on the control, using a low concentration of gibberellic acid $\left(0.05 \mathrm{mg} 100 \mathrm{~mL}^{-1}\right)$. In our study it confirms that gibberellic acid helps to remove seed dormancy in A. hypogaea and, provides enhanced germination of them. Although, this study found that, the highest percentage of germination was a soaking time of 4 hours, Herrera-Corredor et al. (2011) mentioned that, the strain Allium cepa seed soaking with hormone BAP(benzyladenine) larger than $5 \mathrm{~min}$, decrease their percentage of germination. In this sense, there would be the need for more studies with $\mathrm{AG}_{3}$, since they are almost nil at present. 


\section{Efecto de Bacillus en el crecimiento de la planta de $\boldsymbol{A}$. hypogaea}

En plantas de $A$. hypogaea se evaluó la tasa relativa de crecimiento en altura $\left(\mathrm{RGR}_{\text {Altura }}, \mathrm{cm} \mathrm{cm}^{-1}\right.$ día $\left.^{-1}\right)$ y la tasa de crecimiento de diámetro de tallo $\left(\mathrm{RGR}_{\text {Diámetro }} \mathrm{mm} \mathrm{día}^{-1}\right)$, así como el ritmo de emisión foliar durante los 15 y 30 días (Cuadro 3). Para las variables $\mathrm{RGR}_{\text {Diámetro y número }}$ de hojas, no se observaron diferencias significativas por efecto de los inoculantes. Para la variable $\mathrm{RGR}_{\text {Altura }}$, sólo se observaron diferencias significativas $(p>0.05)$ a los 15 días después de la siembra, donde las plantas inoculadas con CBRF12 presentaron mayores valores para esta variable comparado con las plantas del testigo. Nawangsih et al. (2012) reportaron en A. hypogaea un efecto en el incremento de altura por uso de inoculantes bacterianos a partir de la quinta semana ( 35 días) posterior a la siembra de las semillas. Sin embargo, en este estudio sólo se observaron efectos en la segunda semana (15 días después de la siembra), mientras que en la evaluación a los 30 días después de la siembra no se observaron diferencias $(p<0.05)$ en la variable $\mathrm{RGR}_{\text {Altura }}$. Este incremento en altura de la plantas pudo deberse a un mejor desarrollo de los pelos radicales o absorbentes, característico de las primeras semanas de inoculación bacteriana, sin embargo, este incremento no provoca cambios iniciales en la biomasa radical, lo que a la larga podría o no dar lugar a un incremento en la biomasa aérea (Cuevas et al., 2000). El efecto de los inoculantes bacterianos a base de Bacillus spp., ha sido atribuido principalmente a la producción de sustancias estimuladoras del crecimiento vegetal, tales como vitaminas, ácido indolacético y giberélico, y citoquininas (Gutiérrez et al., 2001; Cardenas et al., 2010).
Moreover, no significant effects of naproxen on the germination of $A$. hypogaea were observed. In previous work, naproxen has been considered an inhibitor of the biosynthesis of abscisic acid (ABA), which can increase seed germination (Wan and Li, 2006). Even Hu et al.(2010) reported that, the application of naproxen increased by approximately $12 \mathrm{~h}$ germination up to $96 \%$, six days after application. The application of naproxen was only for 2 to 4 hours, which may have affected the outcome, because the exposure time and the concentration of naproxen are determining factors in the germination of $A$. hypogaea (Matusova et al., 2005).

\section{Bacillus effect on plant growth of $A$. hypogaea}

In plants of $A$. hypogaea relative height growth rate $\left(\mathrm{RGR}_{\text {Height }}, \mathrm{cm} \mathrm{cm}^{-1}\right.$ day $\left.^{-1}\right)$ and the growth rate of stem diameter $\left(\mathrm{RGR}_{\text {Diameter }}, \mathrm{mm} \mathrm{day}^{-1}\right)$ and the leaf emission rate was evaluated during the 15 and 30 days (Table 3 ). For the variables $\mathrm{RGR}_{\text {Diameter }}$ and number of leaves, no significant differences due inoculants were observed. $\mathrm{RGR}_{\text {Height }}$ for variable, significant differences $(p>0.05)$ at 15 days were observed after planting, where CBRF12 inoculated plants showed higher values for this variable compared with the control plants. Nawangsih et al. (2012) reported in $A$. hypogaea an effect on the increase in height by use of bacterial inoculants from the fifth week (35 days) after planting seeds. However, in this study only effects were observed during the second week ( 15 days after seeding), while in the evaluation at 30 days after sowing no differences ( $p<$ 0.05 ) were observed in the variable $\mathrm{RGR}_{\text {Height }}$. This increase in height of the plants could be due to better development

Cuadro 3. Efecto de la inoculación de Bacillus spp., en el crecimiento de las plantas de A. hypogaea después de 15 y 30 días. Table 3. Effect of inoculation of Bacillus spp., on growing plants of $A$. hypogaea, after 15 and 30 days.

\begin{tabular}{|c|c|c|c|c|c|c|}
\hline \multirow[t]{2}{*}{ Cepa bacteriana } & \multicolumn{3}{|c|}{15 días después de la siembra } & \multicolumn{3}{|c|}{30 días después de la siembra } \\
\hline & $\begin{array}{l}\mathrm{RGR}_{\text {Altura }} \\
\left(\mathrm{cm} \mathrm{cm}^{-1} \mathrm{dí}^{-1}\right)\end{array}$ & $\begin{array}{l}\text { RGR }_{\text {Diámetro }} \\
\left(\mathrm{mm} \mathrm{día}^{-1}\right)\end{array}$ & Número de hojas & $\begin{array}{l}\mathrm{RGR}_{\text {Altura }} \\
\left(\mathrm{cm} \mathrm{cm}^{-1} \mathrm{dí}^{-1}\right)\end{array}$ & $\begin{array}{l}\mathrm{RGR}_{\text {Diámetro }} \\
\left(\mathrm{mm} \mathrm{día}^{-1}\right)\end{array}$ & Número de hojas \\
\hline CBTC1 & $9.87 \pm 0.31 \mathrm{ab}$ & $3.31 \pm 0.04 \mathrm{a}$ & $8.00 \pm 0.19 \mathrm{a}$ & $19.53 \pm 0.53 \mathrm{a}$ & $3.70 \pm 0.06 \mathrm{a}$ & $16.40 \pm 0.62 \mathrm{a}$ \\
\hline CBCC57 & $10.15 \pm 0.29 \mathrm{ab}$ & $3.35 \pm 0.04 \mathrm{a}$ & $7.77 \pm 0.24 \mathrm{a}$ & $20.23 \pm 0.70 \mathrm{a}$ & $3.76 \pm 0.05 \mathrm{a}$ & $16.13 \pm 0.73 \mathrm{a}$ \\
\hline CBRF12 & $10.32 \pm 0.36 \mathrm{a}$ & $3.33 \pm 0.04 \mathrm{a}$ & $7.77 \pm 0.29 \mathrm{a}$ & $19.30 \pm 0.70 \mathrm{a}$ & $3.75 \pm 0.06 \mathrm{a}$ & $15.20 \pm 1.03 \mathrm{a}$ \\
\hline Testigo & $9.05 \pm 0.20 \mathrm{~b}$ & $3.28 \pm 0.03 \mathrm{a}$ & $7.70 \pm 0.21 \mathrm{a}$ & $18.00 \pm 0.62 \mathrm{a}$ & $3.65 \pm 0.05 \mathrm{a}$ & $15.73 \pm 0.56 \mathrm{a}$ \\
\hline
\end{tabular}

Letras diferentes en una misma columna indican diferencias estadísticamente significativas (Tukey $\leq 0.05$ ). $R G R=$ tasa relativa de crecimiento de la planta.

Con respecto a la altura de las plantas en la evaluación a los 30 días después de inoculadas con las cepas CBTC1, CBCC57 y CBRF12 (19.30-20.23 cm), se observó que of radical or absorbent characteristic of the first weeks of bacterial inoculation hairs; however, this increase does not cause radical changes in the initial biomass, which could 
en general los valores fueron ligeramente menores a los obtenidos por Dey et al. (2004) en plantas de A. hypogaea $(22.9 \mathrm{~cm})$ a los 45 días después de la siembra y que fueron inoculadas con la rizobacteria (PGPR6, 1998). Anandham et al. (2007) reportaron un crecimiento similar a obtenido en este trabajo en plantas de $A$. hypogaea a los 40 días después de la siembra, donde se observó 19.54 y $19.84 \mathrm{~cm}$ de altura cuando se inocularon con las cepas SWA4 y SWA5 de Thiobacillus sp. Por lo que el crecimiento de las plantas de A. hypogaea inoculadas con Bacillus spp. estuvo en el rango normal de crecimiento que han reportado otros autores en estudios de efecto de inoculantes microbianos.

En el caso de biomasa seca (Cuadro 4), no se observaron diferencias significativas en biomasa seca aérea. En contraste, se observó diferencia significativa $(p<0.05)$ en biomasa seca deraíza los 30 días después de la siembra, dondela inoculación con la cepa CBTC1 causó mayor ganancia de peso $(0.27 \mathrm{~g})$ de raíz en las plantas. Este efecto lento en el crecimiento de la raíz pudo deberse a que la relación simbiótica entre bacteria y raíz no se presentó de manera inmediata, por lo que quizá haya que esperar por lo menos 3 o 4 semanas para que pueda observarse un efecto significativo en el crecimiento vegetal (Cuevas et al., 2000; Dey et al., 2004). eventually or may not lead to an increase in aboveground biomass (Cuevas et al.,2000). The effect of bacterial Bacillus spp based on inoculants has been attributed mainly to the production of plant growth promoting substances such as vitamins, indole and gibberellic acid and cytokinins (Gutiérrez et al., 2001; Cardenas et al., 2010).

Regarding plant height, in the evaluation within 30 days after inoculated with CBTC1, CBCC57 and CBRF12 $(19.30-20.23 \mathrm{~cm})$, strains was observed that in general the values were slightly lower than those obtained by Dey et al. (2004) in plants of A. hypogaea $(22.9 \mathrm{~cm})$ at 45 days after sowing and were inoculated with rizobacteria (PGPR6, 1998). Anandham et al. (2007) reported a similar obtained in this work in growing plants $A$. hypogaea at 40 days after sowing, where noted 19.54 and $19.84 \mathrm{~cm}$ when inoculated with strains SWA5 and SWA4 of Thiobacillus sp., as the plant growth of A. hypogaea inoculated with Bacillus spp. It was in the normal range of growth reported by other authors in studies of effect of microbial inoculants.

In the case of dry biomass (Table 4), no significant differences were observed aerial dry biomass. In contrast, significant differences $(p<0.05)$ was observed in root dry

Cuadro 4. Biomasa seca en plantas $A$. hypogaea sujetas a diferentes tratamientos con Bacillus spp. después de 15 y 30 días. Table 4. Dry biomass in plants $A$. hypogaea subject to different treatments with Bacillus spp. after 15 and 30 days.

\begin{tabular}{llccc}
\hline $\begin{array}{l}\text { Cepa } \\
\text { bacteriana }\end{array}$ & \multicolumn{2}{l}{$\begin{array}{l}\text { 15 días después de la siembra } \\
\text { Biomasa seca de hojas }(\mathrm{g})\end{array}$} & Biomasa seca de raíz $(\mathrm{g})$ & $\begin{array}{l}\text { 30 días después de la siembra } \\
\text { Bioma seca de hojas }(\mathrm{g}) \text { Biomasa seca de raíz }(\mathrm{g})\end{array}$ \\
\hline CBTC1 & $0.51 \pm 0.02 \mathrm{a}$ & $0.15 \pm 0.01 \mathrm{a}$ & $1.23 \pm 0.10 \mathrm{a}$ & $0.27 \pm 0.02 \mathrm{~b}$ \\
CBCC57 & $0.56 \pm 0.03 \mathrm{a}$ & $0.14 \pm 0.01 \mathrm{a}$ & $1.18 \pm 0.10 \mathrm{a}$ & $0.24 \pm 0.03 \mathrm{ab}$ \\
CBRF12 & $0.52 \pm 0.03 \mathrm{a}$ & $0.14 \pm 0.01 \mathrm{a}$ & $1.17 \pm 0.13 \mathrm{a}$ & $0.22 \pm 0.02 \mathrm{ab}$ \\
Testigo & $0.47 \pm 0.02 \mathrm{a}$ & $0.12 \pm 0.01 \mathrm{a}$ & $1.10 \pm 0.07 \mathrm{a}$ & $0.19 \pm 0.02 \mathrm{a}$ \\
\hline
\end{tabular}

Letras diferentes indican diferencias estadísticamente significativas (Tukey $\leq 0.05$ ).

Por otro lado, las cepas CBCC57 y CBRF12 tuvieron un efecto intermedio en la ganancia de peso de la raíz seca. En general el peso seco de las plantas observadas en el presente estudio, fueron mayores que lo observado por Taurian et al. (2010) a los 35 días después de la siembra, usando Pseudomonas fluorescens $(0.16 \mathrm{~g})$ y Pantoea agglomerans $\mathrm{J} 49(0.21 \mathrm{~g})$ como agentes promotores de crecimiento. En este sentido, se considera que el uso de bacterias nativas podría ayudar a largo plazo a mejorar la absorción nutricional de la planta y consecuentemente a mejorar su rendimiento (Dey et al., 2004). biomass 30 days after sowing, where CBTC1 inoculation with the strain caused larger weight gain $(0.27 \mathrm{~g})$ in plant root. This slow effect on root growth could be due to the symbiotic relationship between bacteria and roots that did not show up immediately, so we may have to wait at least 3 or 4 weeks in order to observe a significant effect on the plant growth (Cuevas et al., 2000; Dey et al., 2004).

Furthermore, the strains CBRF12 and CBCC57 had an intermediate effect on the weight gain of the dried root. Generally, the dry weight of plants observed in this study 


\section{Conclusiones}

El estado de latencia de la semillas de $A$. hypogaea puede ser interrumpida por tratamiento con ácido giberélico. El tratamiento de semillas con ácido giberélico (10 mg en 100 $\mathrm{mL}^{-1}$ ) por $4 \mathrm{~h}$ de inmersión, incrementa significativamente el porcentaje de germinación. El naproxeno no tuvo efecto alguno en la germinación. La inoculación de las cepas de Bacillus spp. CBTC1, CBCC57 y CBRF12 mostró poco efecto en la promoción de crecimiento e incremento de peso seco aéreo y de raíz del cultivo de $A$. hypogaea. En este sentido, sólo se observaron cambios significativos en la altura a los 15 días en plantas inoculadas con la cepa CBRF12 y en biomasa seca de raíz a los 30 días, en plantas inoculadas con la cepa CBTC1.

\section{Agradecimientos}

Los autores agradecen a la Fundación Produce Chiapas al proyecto Núm. 2221, por el financiamiento de este trabajo de investigación.

\section{Literatura citada}

Anandhama, R.; Sridarb, R.; Nalayinic, P.; Poonguzhalia, S.; Madhaiyana, M. and Tongmin, S. A. 2007. Potential for plant growth promotion in groundnut (Arachis hypogaea L.) cv. ALR-2 by co-inoculation of sulfur-oxidizing bacteria and Rhizobium. Microbiological Res. 162:139-153.

Atrip, N. and O'Reilly, C. 2007. Germination response of alder and birch seeds to applied gibberellic acid and priming treatment combination with chilling. Ann. Forest Sci. 64:385-394.

Cardenas, D. M.; Garrido, M. F.; Bonilla, R. R. y Baldani, V. L. 2010. Aislamiento e identificación de cepas de Azospirillum sp. en pasto guinea (Panicum maximum Jacq.) del Valle del Cesar. Pastos y Forrajes. 33(3):1-1.

Cassán, F.; Sgroy, V.; Perrig, D.; Masciarelli, O. y Luna, V. 2008. Producción de fitohormonas por Azospirillum sp. aspectos fisiológicos y tecnológicos de la promoción del crecimiento vegetal. In: Cassán, F. and García de Salamone, I. (Eds.), Azospirillum sp., cell physiology, plant interactions and agronomic research in Argentina. Asociación Argentina de Microbiología. 61-78 p.

Causton, D. R. and Venus, J. C. 1981. The biometry of plant growth. Edward Arnold, London, England. 307 p.

Cuevas, P. C.; Medina, B. N.; Díaz, L. G. S. y Morejón, R. R. 2000. Efecto de la biofertilización con bacterias rizoféricas en el cultivo del tomate. Avances. 2(2):15-21. were larger than those observed by Taurian et al. (2010) at 35 days after sowing, using Pseudomonas fluorescens $(0.16 \mathrm{~g})$ and Pantoea agglomerans $\mathrm{J} 49(0.21 \mathrm{~g})$ as growthpromoting agents. In this regard, it is considered that the use of native bacteria could help to improve long term nutritional plant uptake and consequently improve yield (Dey et al., 2004).

\section{Conclusions}

Dormancy of seeds of A. hypogaea can be disrupted, treated with gibberellic acid. Seed treatment with gibberellic acid (10 mg in $100 \mathrm{~mL}^{-1}$ ) immersion for $4 \mathrm{~h}$, significantly increased the percentage of germination. Naproxen had no effect on germination. Inoculating strains of Bacillus spp. CBTC1, CBRF12 and CBCC57 showed little effect in promoting growth and increasing shoot dry weight and root of $A$. hypogaea. So, only significant changes were observed in the height after 15 days in the inoculated plants with CBRF12 strain and root dry biomass after 30 days, inoculated with strain CBTC1 plants.

End of the English version

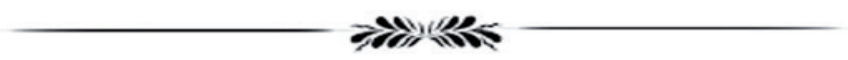

Dey, R.; Pal, K. K.; Bhatt, D. M. and Chauhan, S. M. 2004. Growth promotion and yield enhancement of peanut (Arachis hypogaea L.) by application of plant growth-promoting rhizobacteria. Microbiological Res. 159:371-394.

Duque, M. E. C. 2013. Comparación agronómica de diez cultivares de maní (Arachis hypogea; Fabacea) en Ipala, Chiquimula. Tesis profesional. Universidad Rafael Landívar-Facultad de Ciencias Ambientales y Agrícolas. Guatemala, Guatemala.

Enríquez, Q. J. F. y Quero, C. A. R. 2001. Producción de semilla de cacahuate forrajero con siete dosis de cal y tres fechas de cosecha. Téc. Pecu. Méx. 39 (1):31-38.

Financiera Rural(FR). 2011. Monografía del cacahuate. Dirección general adjunta de planeación estratégica y análisis sectorial. Financiera Rural, México, D. F.

Gómez, S. M.; Burow, G.; Burke, J. J.; Belamkar, V.; Puppala, N. and Burow, M. D. 2001. Heat stress screening of peanut (Arachis hypogaea $L$.) seedlings for acquired thermotolerance. Plant Growth Regul. 65(1):83-91.

Grosso, N. R.; Nepote, V. and Guzmán, C. A. 2000. Article chemical composition of some wild peanut species (Arachis L.) Seeds. J. Agric. Food Chem. 48 (3):806-809.

Gutiérrez, M. F. J.; Ramos, S. B.; Probanza,A.; Mehouachi, J.; Tadeo, R.F. and Talon, M. 2001. The plant-growth-promoting rhizobacteria Bacillus pumilus and Bacillus licheniformis produce high amounts of physiologically active gibberellins. Physiol. Plant. 111(2):206-211. 
Hu, B.; Wan, X.; Liu, X.; Guo, D. and Li, L. 2010. Abscisic acid (ABA)mediated inhibition of seed germination involves a positive feedback regulation of ABA biosynthesis in Arachis hypogaea L. Afr. J. Biotechnol. 9(11):1578-1586.

Herrera-Corredor, C.; Carrillo-Castañeda, G.; González-Hernández, V.; Carrillo-Salazar, J.; Peña-Valdivia, C. y García-Nava, J. 2011. Tratamientos químicos para recuperar la germinación en semillas de cebolla. Rev. Chapingo Ser. Hortic. 17 (2):63-72.

INEGI (Instituto Nacional de Estadística, Geografía e Informática). 2010. Instituto Nacional de Estadística y Geografía, México, D. F.

Ingale, S. and Shrivastava S. K. 2011. Nutritional study of new variety of ground nut (Arachis hypogea) JL-24 seeds. AJFS. 5(8) 490-498.

Kambiranda, D. M.; Vasanthaiah, H. K. N.; Katam, R.; Ananga, A.; Basha, S. M. and Naik, K. 2011. Impact of drought stress on peanut (Arachis hypogea) productivity and food safety. In: plants and environment. Vasanthaiah, H. (Ed.). InTech. 272 p.

Lin, Z.; Zhong, S. and Grierson, D. 2009. Recent advances in ethylene research. J. Exp. Bot. 60 (12):3311-3336.

Matusova, R.; Rani, K.; Verstappen, F. W.; Franssen, M. C.; Beale, M. H. and Bouwmeester, H. J. 2005. The strigolactone germination stimulants of the plant-parasitic Striga and Orobanche spp. are derived from the carotenoid pathway. Plant Physiol. 139(2):920-934.

Mohammadi, G. R. 2013. Alternative weed control methods: a review. In: Soloneski, S. (Ed.), weed and pest control-conventional and new challenges. InTech, Agric. Biol. Sci. 6. 17-159 pp.

Muñoz, V.; Ibáñez, F.; Tonelli, M.; Valetti, L.; Anzuay, M. and Fabra, A. 2011. Syst. Appl. Microbiol. 34(6):446-52.

Navarro, H.; Navarro, S. and Finkelman, S. 2012. Hermetic and modified atmosphere storage of shelled peanuts to prevent free fatty acid and aflatoxin formation. In: Athanassiou, C.; Kavallieratos, N. and Weintraub, P. (Eds.). Integrated Protection of Stored Products. 81:83-192.

Nawangsih, A. A.; Aditya, R.; Tjahjono, B.; Negishi, H. and Suyama, K. 2012. Bioefficacy and characterization of plant growthpromoting bacteria to control the bacteria wilt disease of peanut in Indonesia. Journal of ISSAAS. 18(1):185-192.
Ossom, E. M. and Rhykerd, R. L. 2008. Implication of associating sweet potato (Ipomoea babatas) with different groundnut (Arachis hyogea) population on tuber yield and soil and tuber chemical properties.American-Eurasian J.Agric. Environ. Sci. 3(1):63-69.

Qin, F.; Xu, H.; Lü, D. and Takano, T. 2012. Responses of hypocotyl elongation to light and sowing depth in peanut seedlings. J. Food, Agri. Environ. 10(2):607-612.

Ranal, M.; García, De S. D.; Resende, F. W. and Mendes, R. C. 2009. Calculating germination measurements and organizing spreadsheets. Rev. Bras. Bot. 32(4):849-855.

Saravanakumar, D. and Samiyappan, R. 2007. ACC deaminase from Pseudomonas fluorescens mediated saline resistance in groundnut (Arachis hypogea) plants. J. Appl. Microbiol. 102:1283-1292.

Shweta, B.; Maheshwari, D. K.; Dubey, R. C.; Arora, D. S.; Bajpai, V. K. and Kang, S. C. 2008. Beneficial effects of fluorescent pseudomonads on seed germination, growth promotion, and suppression of charcoal rot in groundnut (Arachis hypogea L.). J. Microbiol. Biotechnol. 18 (9):1578-1583.

Sosa-Pech, M.; Ruiz-Sánchez, E.; Mejía-Bautista, M.; Reyes-Ramírez,A.; Cristóbal-Alejo, J.; Valencia-Botín, A. y Gutiérrez- Alonzo. O. 2012. Actividad antagónica in vitro de aislados de la clase Bacilli de la península de Yucatán contra cuatro hongos fitopatógenos. Universidad y Ciencia Trópico Húmedo. 28(3): 279-284.

Statistical Analysis System (SAS) Institute. 2007. SAS user's guide. Statistics. Version 8. SAS Inst., Cary, NC. USA. Quality, and elemental removal. J. Environ. Qual. 19:749-756.

Taurian, T.; Anzuay, M.; Angelini, J.; Tonelli, M.; Ludueña, L.; Pena, D.; Ibáñez, F. and Fabra, A. 2010. Phosphate-solubilizing peanut associated bacteria: screening for plant growth-promoting activities. Plant Soil. 329(1-2):421-431.

Thammina, C.; He, M.;Yu, H.; Chen, Y.; Gai, Y.; Cao, K.; Lu, L.; Zhao, D.; Wang, Y.; McAvoy, R.; Ellis, D. and Li., Y. 2012. Continuous biosynthesis of abscisic acid (ABA) may be required for maintaining dormancy of isolated embryos and intact seeds of Euonymus alatus. Plant Cell Tissue Organ Cult. 108:493-500.

Wan, X. R. and Li, L. 2006. Regulation of ABA level and water-stress tolerance of Arabidopsis by ectopic expression of a peanut 9-cis-epoxycarotenoid dioxygenase gene. Biochem. Biophys. Res. Commun. 347:1030-1038. 